doi:10.2478/mape-2021-0032

Date of submission to the Editor: 03/2021

Date of acceptance by the Editor: 05/2021

MAPE 2021, volume 4, issue 1, pp. 355-364

Patrycja Hąbek

ORCID ID: 0000-0002-7545-1637

Silesian University of Technology, Poland

Justyna Czarnecka

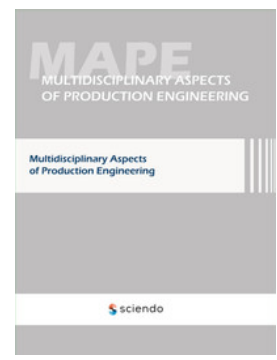

\title{
INTRODUCTION
}

Supplier development plays a key role in supply chain management, so its importance cannot be underestimated (Krause, Handfield and Scannell, 1998). Supplier development contributes to the development of companies in terms of sourcing and maintaining appropriate suppliers, quality, technology, financial capacity and continuous improvement (Rajput and Bakar, 2012). The main goal of supplier development is a long-term mutually beneficial contract with improved supplier performance (Krause, Handfield and Scannell, 1998). Good supplier performance is important to meet manufacturers' expectations (Routroy and Pradhan, 2011). However, nowadays the goals of achieving an appropriate level of quality and reducing costs are not enough to meet the competition in the market. Companies are expected to take responsibility for the social and environmental impacts of their activities. Pressure in this direction is exerted by various stakeholder groups, including NGOs, regulators, investors and the public. A socially and environmentally responsible company is obliged to ensure the responsibility of not only its company but also needs to take into account the whole supply chain, especially relations with its suppliers. Therefore the focus on cost and quality issues in supply chain management must be expanded to include environmental and social aspects (Porter and Kramer, 2006). It seems that a good solution in this matter may be the use of a mechanism that has been operating in enterprises for years in the form of the supplier development process. The aim of the article is to present a proposal to incorporate sustainability principles into the existing supplier development process. The proposal is based on the case study of a manufacturing company.

\section{SUSTAINABLE SUPPLIER DEVELOPMENT}

\section{Supplier development}

Stakeholders engagement is a key concept in the creation and implementation of activities in the area of corporate social responsibility (CSR). Stakeholders can be defined as any person or group of persons that can influence the 
organization or be influenced by an organization (Freeman, 1984). One of the key stakeholders for manufacturing companies are their suppliers. For the enterprise, suppliers are a group of external stakeholders and without them, the enterprise would not be able to survive and develop (Rybak, 2004). The supplier plays a key role in the supply chain management. Growing customer requirements and increasing competition have a huge impact on the development and changes in the management of the logistics system. Therefore the sound partnership between suppliers and buyers is a crucial issue, because it affects the continuity of the production processes and it directly influence the quality of the component produced (Kania, 2012).

In the area of supplier development it can be specified such tasks as:

- defining the client's needs in relation to the materials and services obtained,

- determining the level of acceptance of the materials and services provided,

- determining the possibility of controlling the level of deliveries and the impact of their quality level on the customer's production process,

- estimating the losses of failure to meet expectations, including complaints or lack of compensation, while not monitoring the process of closing the complaint,

- carrying out projects increasing the quality level of delivered materials and services

- mutual learning of the product by the supplier and the customer,

- formal definition of requirements by adopting appropriate provisions, including quality agreements, defect catalogues and adopted quality levels,

- supplier auditing, preparation of audit schedules, methodology for verification of production processes,

- defining measurable determinants of suppliers' qualifications and their production processes,

- calculation of savings obtained as a result of the implemented corrective actions.

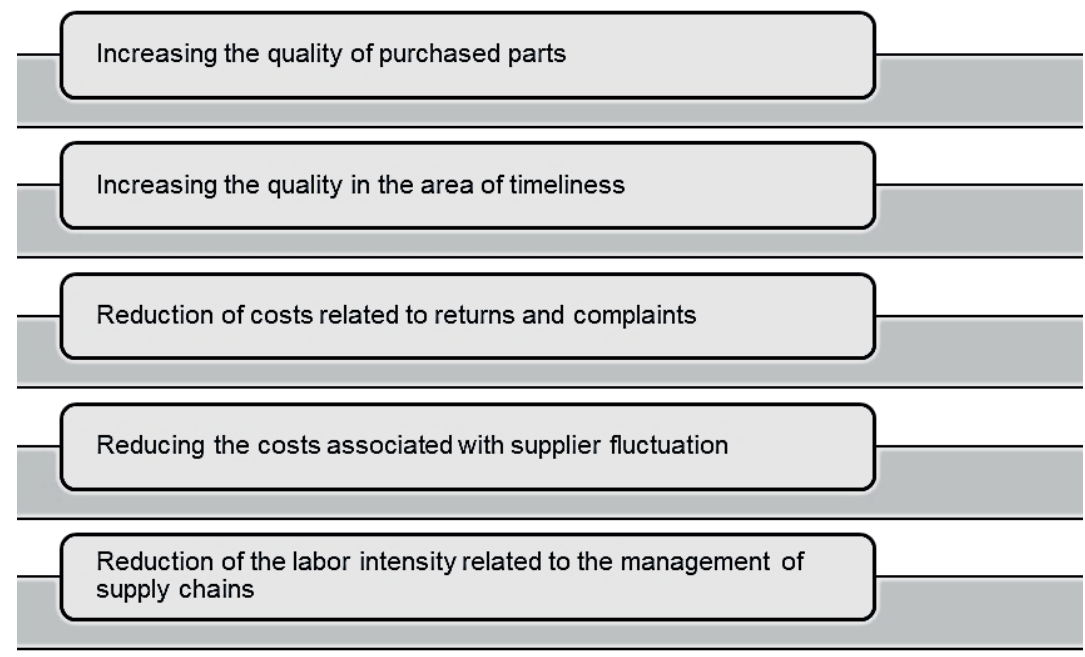

Fig. 1 Benefits of supplier development process implementation

Source: J. Czarnecka "Ocena procesu rozwoju dostawcy pod względem założeń zrównoważonego rozwoju w przedsiębiorstwie produkującym akumulatory do elektronarzędzi" Master thesis, unpublished, March, 2021. 
The benefits of implementing supplier development process are shown at Figure 1.

\section{Including the assumptions of sustainable development in the supplier development process}

Social responsibility is treated as a concept supporting the fulfilment of the principles of sustainable development at the enterprise level; allows you to improve the functioning of the organization in a changing environment. It indicates the direction of action for enterprises aware of their social and environmental impacts in terms of strengthening relations with various groups of stakeholders, as well as additional opportunities for achieving a better competitive position (Rudnicka A., 2012). Generally, it can be said that it is the company's responsibility for its impact on society (EC Communication, 2012). A socially responsible supplier development (SRSD) can be defined as the specific supplier development efforts of a buyer to improve the ability of its major suppliers to implement the concept of corporate social responsibility. Thanks to the implementation of SRSD, it is possible to improve the sustainability results of both suppliers and buyers (Lu, Lee and Cheng, 2012; Ryszko, 2017; Busse, 2016). Social responsible supplier development practices are becoming more and more popular among academia, business, and various international organizations, such as ISO or Global Reporting Initiative. The activities of international organizations on this topic have resulted in the development of standards and guidelines aimed at supporting organizations in implementing socially responsible supply chain management practices (Hąbek and Lavios, 2020). The concept of CSR in literature is very differently defined. This concept is multidimensional and is influenced by many factors, such as progressing globalization or increasing competition. CSR definitions are formulated both by various institutions and the enterprises themselves, and their multiplicity, especially in the case of enterprises, may result, for example, from the different conditions in which they operate. Currently, the most frequently quoted definition of corporate social responsibility is the one proposed by the International Standard ISO 26000 - Guidance on Social Responsibility. According to this standard the CSR concept concern the responsibility of an organization for the impact of its decisions and actions on society and the environment through transparent and ethical behaviour in key areas such as: organizational governance, human rights, labour practices, the environment, fair operating practices, consumer issues, social commitment and local community development. According to the above definition, a socially responsible organization takes into account the opinions of stakeholders, acts in accordance with the law and international standards of behaviour and contributes to the sustainable development of society (PN-ISO 26000:2012). Figure 2 shows the areas of corporate social responsibility according to the ISO 26000 Standard. In practice, corporate social responsibility (CSR) can be understood as investing in human resources, environmental protection, relations with the interested 
parties and informing about these activities, which contributes to the increase of the company's competitiveness and shaping the conditions for sustainable social and economic development (PN-ISO 26000:2012). The most popular practices of incorporating sustainability into supply chains include supplier codes of conduct, integration of sustainability in sourcing strategies, monitoring and auditing of suppliers, sustainability data collection and participation in collaborative initiatives related to supply chains (BSR/GlobeScan, 2015).

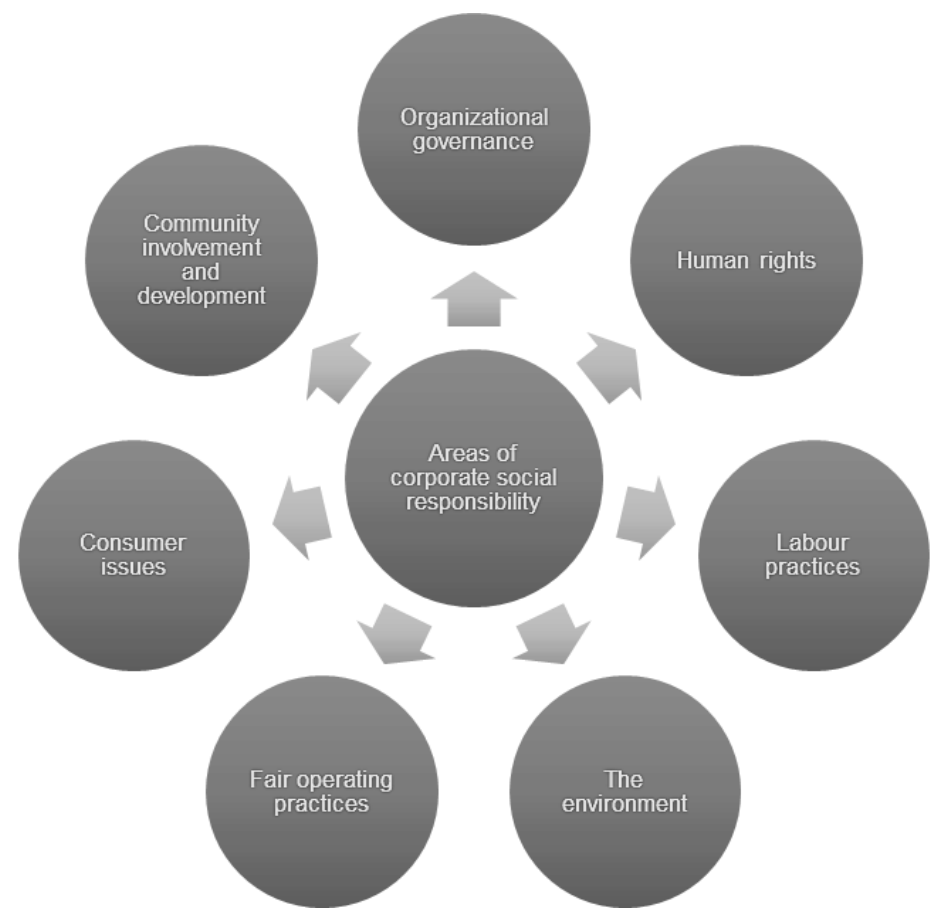

Fig. 2 Areas of corporate social responsibility

Source: based on PN-ISO 26000:2012

\section{CASE STUDY}

The analysed company is a producer of advanced lithium-ion batteries. The company designs and manufactures batteries for bicycles, electric tools and scooters. It employs about 850 people, produces about 2.8 million batteries per year, has manual production as well as semi-automatic production. Extensive knowledge in the field of high-volume production and a flexible approach allows to design reasonable economic production lines. The company constantly improves its competences by searching for optimal solutions in the field of designing and implementing new technologies. They carry out benchmarks of other batteries in order to be able to identify weaknesses and strengths and thus develop the manufactured products. The company has a certified quality management system according to the requirements of ISO 9001:2015, environmental management system ISO 14001:2015 and occupational health and safety system ISO 45000:2018. 


\section{Supplier development process - current state}

The company cooperates with 90 suppliers who deliver various types of components, from which, after assembly, we ultimately receive a lithium-ion battery. Suppliers are divided into key and qualified. The suppliers were classified on the basis of the type of components and the impact they have on the final product.

The supplier development process consists of sub-processes such as (Fig. 3): supplier selection process and periodic supplier assessment, which results indicate the areas that should be focused on during the supplier development.

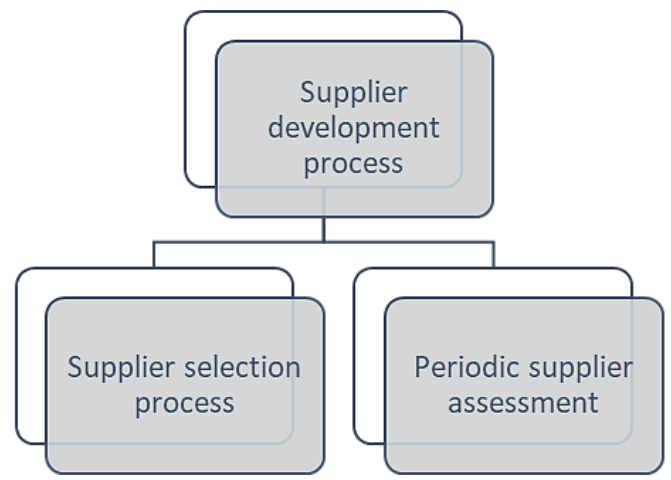

Fig. 3 Supplier development process in the analysed company

Source: J. Czarnecka „Ocena procesu rozwoju dostawcy pod względem założeń zrównoważonego rozwoju w przedsiębiorstwie produkującym akumulatory do elektronarzędzi" Master thesis, unpublished, March, 2021.

\section{Supplier selection process}

As part of the supplier selection process, when signing the contract, the supplier signs the supplier's code of conduct, which defines the company's expectations towards suppliers in relation to: human rights, labour relations, health and safety, environmental protection and business ethics. The analysed company makes every effort to: disseminate the supplier code of conduct to new and existing suppliers; verify compliance with the supplier code of conduct by existing suppliers and work with them to help improve their business practices if they do not meet the requirements. The supplier code of conduct provides information on actions the company expects should be taken by suppliers to ensure compliance with the statements included in the code. The supplier's code of conduct applies to all suppliers and service providers that cooperates with the analysed company.

\section{Periodic supplier assessment}

A supplier performance rating (QSPR - Quarterly Supplier Performance Rating) is performed every three months. The purpose of this evaluation is to monitor, evaluate and develop approved suppliers on a regular, periodic time frame. The supplier development leader is responsible for carry out the supplier evaluation. Purchasing, material planning and quality departments are responsible for creating and updating the list of suppliers to be monitored. After each quarter, 
the quality, purchasing, and material planning departments calculate a supplier performance score.

Supplier performance evaluation consists of:

- PPM assessment (quality department),

- evaluation of complaints (quality department),

- delivery evaluation (material planning department),

- customer service assessment (purchasing department).

The results of the periodic supplier evaluation are sent to suppliers by the supplier development engineer. Any supplier ranked in QSPR below "A" level is considered a high risk supplier and is required to submit an improvement plan. After receiving the improvement plan, the quality engineer verifies it and if he has any reservations or comments, he sends them back with instructions for improvement. After the engineer approves the improvement plan, the supplier has a specified time to implement the actions. The supplier is obliged to report on the progress of the implementation of activities. After the planned activities are implemented, the supplier development engineer plans a teleconference with the supplier to discuss the implemented activities. The supplier evaluation after the implementation of activities takes place at the next periodic evaluation. The supplier development engineer conducts training courses, workshops for the supplier with a grade lower than "A". First, it is verified in which area, training should be carried out or workshops, then the engineer and supplier set the appropriate date for training. Depending on the area, training can take place at the supplier's premises, company office or online. Suppliers supplying components to analysed company are audited every two years. If the supplier does not show appropriate improvement actions and does not show willingness to cooperate, the company starts looking for a new supplier.

Concluding, in the current supplier development process, sustainability is considered only at the stage of signing the supplier code of conduct. This is the only place where information on sustainable development is provided. The company did not consider the area of sustainable development as part of supplier development. The analysed company did not conduct any training courses and did not assess suppliers in terms of sustainable development.

\section{Supplier Sustainability Development Programme}

Based on the analysis of the current state and an interview among the company's employees responsible for purchasing and quality assurance activities in order to include the principles of sustainable development into the supplier development it was decided to develop a comprehensive supplier development program. It was proposed that the supplier development program should be divided into four stages (see Figure 4).

In phase 1 suppliers will be introduced to the new updated supplier code of conduct. A purchasing representative will communicate the sustainability requirements to each supplier. Each of the suppliers will be obliged to 
disseminate its content among their employees and confirm the fact of having read its provisions by placing appropriate signatures.

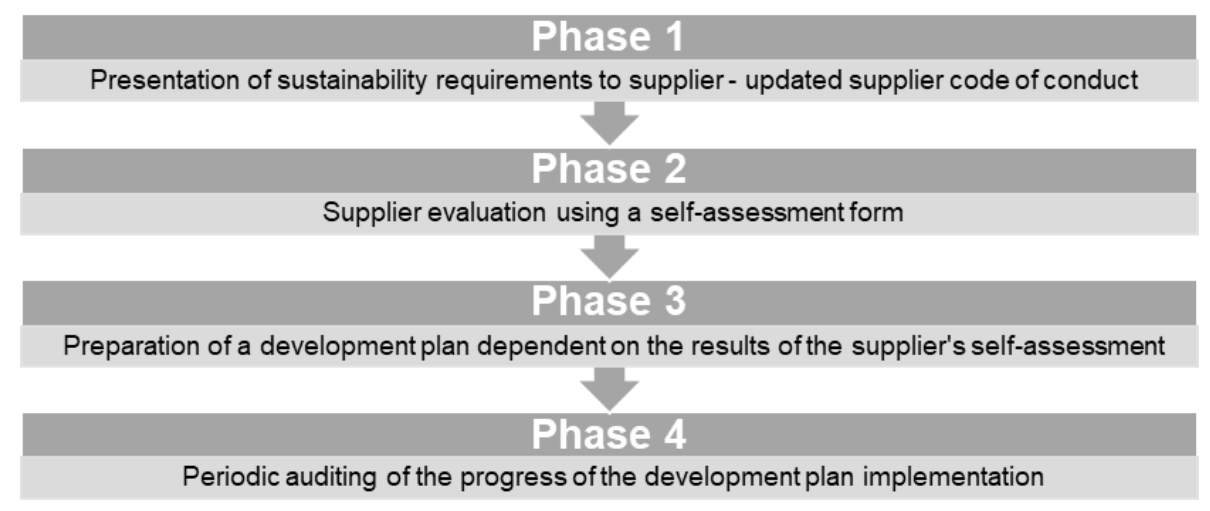

Fig. 4 Stages of the supplier sustainability development programme

Source: based on: J. Czarnecka „Ocena procesu rozwoju dostawcy pod względem założeń zrównoważonego rozwoju w przedsiębiorstwie produkującym akumulatory do elektronarzędzi", Master thesis, unpublished, March, 2021.

The phase 2 includes an assessment of suppliers, for this purpose the authors of the article propose to use a self-assessment tool. The questionnaire consists of 26 questions (see Table 1). The questions are grouped into categories: management, environment, labour relations, social relations and business environment. The questionnaire is sent to the supplier by an employee of the purchasing department. Self-assessment results are sent in by the supplier and reviewed by the supplier development engineer. In this form, the supplier has the opportunity to indicate his own opinion on the area and the way of the support he expect from the company concerning the sustainability implementation.

The phase 3 is training for suppliers. Based on the results of suppliers' selfassessment, training or other forms of development for suppliers will be prepared (e.g. workshops, support in the implementation of system solutions, CSR standards, sharing good practices in areas where the supplier shows deficiencies, joint product improvement or manufacturing processes taking into account the assumptions of sustainable production). The quality engineer prepares a supplier development plan focused on those areas with the lowest self-assessment scores achieved.

After the training and the supplier's improvement plan implementation, phase 4 of the supplier development program follows. The phase 4 is based on periodic supplier audits conducted by a supplier development engineer. Audits will be aimed at monitoring the progress in implementing the supplier's sustainability and the results of the audit will indicate whether the supplier has implemented an improvement plan effectively and whether the training has been successful. 
Table 1 Proposal of self-assessment questionnaire for suppliers

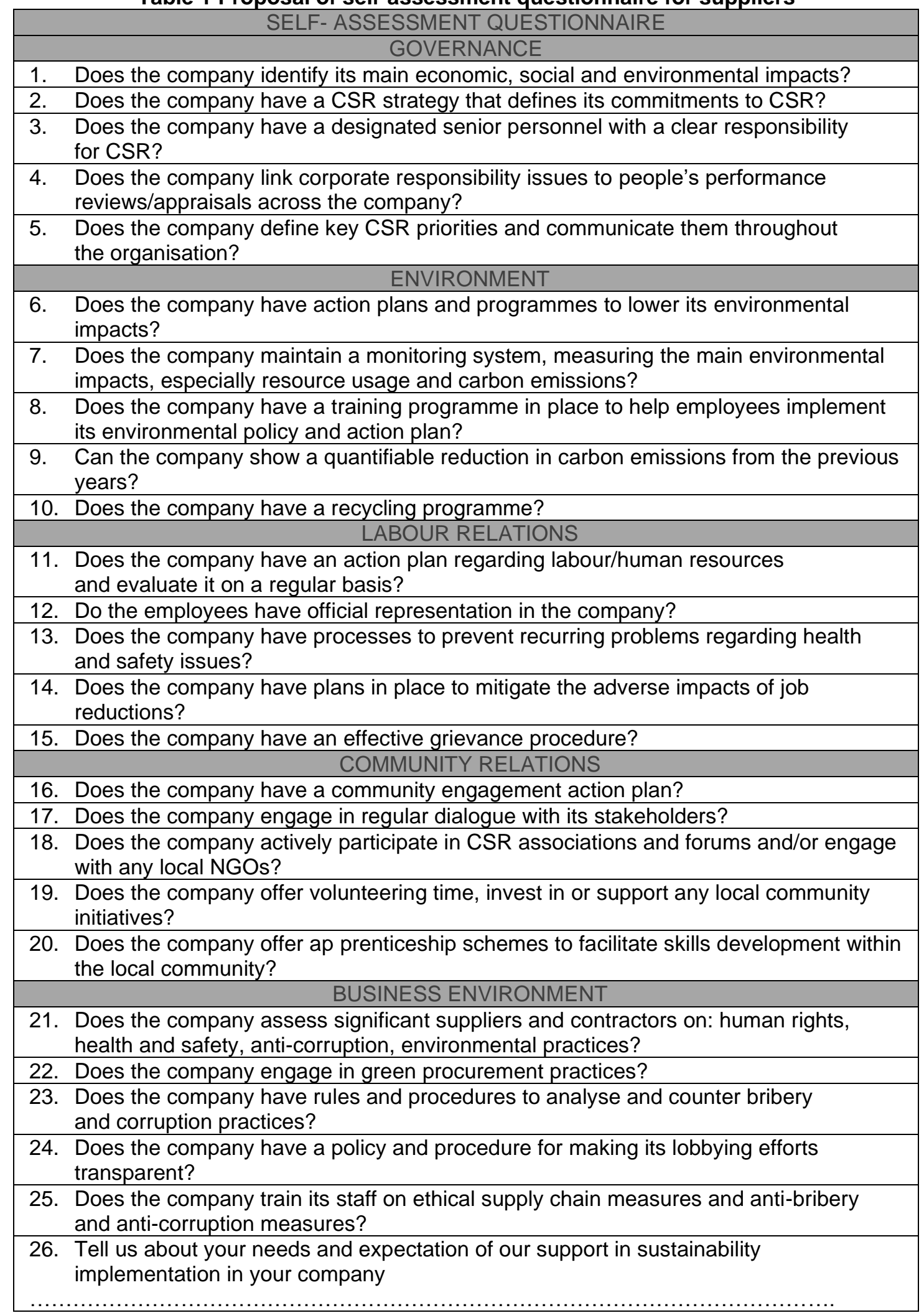

Source: based on: CSR Self-Assessment Handbook for Companies, 2010, UNDP, https://www.spcc.pl/images/file/Forums_Workhops/CSR_Self_assesment_UNDP.pdf 


\section{CONCLUSIONS}

Supplier development is an investment of the manufacturer's time and effort to improve or maintain the required level of quality, timely deliveries and responsiveness. In addition to these important criteria for collaborating with suppliers, sustainability performance issues are now becoming more and more important. A socially and environmentally responsible company should consider not only its own impact but the whole supply chain as only a comprehensive approach has a chance to succeed in pursuit of sustainable development.

Incorporating sustainability into supplier development process have the potential to positively influence the CSR performance of the supplier as well as the producer. The necessary condition is the active engagement of both sides in this process. The authors propose in the paper the supplier sustainability development programme which consist of four stages. The crucial step in this programme seems to be the self-assessment activities. The results of this stage will help to provide the supplier with dedicated support in the area of sustainability which will be the answer to his real needs. The outcome should result in increase of sustainability performance for the supplier as well as producer. Spreading the sustainability into suppliers may be applied by already existing supplier development process or/and can be proposed as a separate sustainability supplier development program.

\section{ACKNOWLEDGEMENT}

The research was conducted with the support of the statutory work project number 13/030/BK-21/0065.

\section{REFERENCES}

BSR/GlobeScan (2015) State of Sustainable Business Survey. Available at: https://www.bsr.org/reports/BSR_GlobeScan_State_of_Sustainable_Business_ 2015.pdf.

Busse, C., Menglei N., Schleper M.C. and Wagner S.M. (2016). Supplier development for sustainability: contextual barriers in global supply chains, International Journal of Physical Distribution \& Logistics Management. Emerald Group Publishing Limited, 46(5), pp. 442-468. doi:10.1108/IJPDLM-12-2015-0300.

Czarnecka J. (2021) Ocena procesu rozwoju dostawcy pod względem założeń zrównoważonego rozwoju w przedsiębiorstwie produkującym akumulatory do elektronarzędzi, Master thesis, unpublished, March.

EC Communication „A renewed EU strategy 2011-2014 for Corporate Social Responsibility", 17 January 2012, www.eurocoop.coop, pp. 2-3

Freeman R.E. (1984) Strategic Management: A stakeholder approach, Pitman, London. Hąbek P., Villahoz J.J.L. (2020) Socially responsible supplier development. Practices of automotive industry in: Multidisciplinary Aspects of Production Engineering. Monograph. Social Sciences. Pt. 2. Ed. Katarzyna Midor, Warszawa: Sciendo, pp. 707-719.

Kania R. (2012) Odmiany i atrybuty relacji - przedsiębiorstwo i jego dostawca w motoryzacyjnym łańcuchu dostaw, „Gospodarka Materiałowa i Logistyka”, nr 9.

Krause D.R., Handfield R.B., Scannell T.V. (1998) An empirical investigation of supplier development: reactive and strategic processes, Journal of Operations Management, December, Vol. 17, No. 1 
Krause D.R., Handfield R.B., Scannell T.V. (1998) An empirical investigation of supplier development: reactive and strategic processes, Journal of Operations Management, December, Vol. 17, No. 1

Lu, R. X. A., Lee, P. K. C. and Cheng, T. C. E. (2012) 'Socially responsible supplier development: Construct development and measurement validation', International Journal of Production Economics. Elsevier, 140(1), pp. 160-167. doi:10.1016/J.IJPE.2012.01.032

PN-ISO 26000:2012 Wytyczne dotyczące społecznej odpowiedzialności, PKN, 2012

Porter, M.E., Kramer M.R. (2006) 'Strategy \& Society, the Link between Competitive Advantage and Corporate Social Responsibility Harvard Business Review, Vol. 84, No. 12, pp. 78-92. $1^{\text {st }}$ International Conference on Information Interaction in Context. doi:10.1287/mnsc.1090.1070.

Rajput, A. Bakar, A. (2012) "Elements, benefits and issues of supplier development contextualizing multiple industries", International Journal of Basic and Applied Scientific Research, Vol. 11, No. 2

Routroy, S. Pradhan, S.K. (2011) "Evaluating the critical success factors of supplier development: a case study", Benchmarking: An International Journal, Vol. 20

Rudnicka A., (2012) CSR - doskonalenie relacji społecznych w firmie, Wolters Kluwer Polska, Warszawa.

Rybak M. (2004) Etyka menedżera - społeczna odpowiedzialność przedsiębiorstwa, PWN, Warszawa.

Ryszko, A. (2017) 'Corporate Social Responsibility Reporting and Green Supply Chain Management - Case of Poland', in Carpathian Logistics Congress (CLC' 2016).

UNDP (2010) CSR Self-Assessment Handbook for Companies, 2010, https://www.spcc.pl/images/file/Forums_Workhops/CSR_Self_assesment_UND P.pdf

\begin{abstract}
Nowadays companies are more and more often expected to take responsibility for social and environmental impacts of their activities. When doing business social responsible company takes into consideration a wide range of its stakeholder's expectations but also spread the social and environmental responsibility idea within the supply chain. Suppliers are the key stakeholders which directly influence the producer in terms of costs and quality of the offered products. However suppliers who offer high quality materials or components at an attractive price but at the same time not paying attention to their social and environmental impacts may devastate the buyer sustainability performance. Therefore the companies are trying to support suppliers in assuring their social and environmental responsibility as with this approach both sides benefit. In the study the authors used the case study method to present the proposal of integrating sustainability issues into already functioning supplier development process of a manufacturing company.
\end{abstract}

Keywords: supplier development, sustainable development, corporate social responsibility, supplier development program, sustainability 